\title{
Hubungan frekuensi menyikat gigi dengan tingkat kebersihan gigi dan mulut siswa sekolah dasar negeri di kecamatan Palaran kotamadya Samarinda provinsi Kalimantan Timur
}

\author{
(The relation of frequency of teeth brush with oral hygiene of state elementary \\ school children in Palaran area district of Samarinda province of east Kalimantan)
}

Silvia Anitasari* dan Nina Endang Rahayu**

* Bagian Mikrobiologi Fakultas Kedokteran Universitas Mulawarman

** Dinas Kesehatan Kota Samarinda Provinsi Kalimantan Timur

\begin{abstract}
The aim of this study was to get information about the relation of frequency of teeth brush to oral hygiene of elementary school children in Palaran Samarinda. The samples were 1650 first to sixth grade elementary school children taken from 10 state elementary schools at Palaran Samarinda. Oral hygiene was measured by OHI-S index, and frequency of teeth brush was measured by questionnaire. Statistical analysis was performed with chi-square test. The results showed that $6.73 \%$ have good oral hygiene, 59.03 $\%$ moderate and $34.24 \%$ poor. The frequency of teeth brush showed that $18 \%$ at $1 x, 34.24 \%$ at $2 x, 61.88 \%$ at $3 x ; 1.70 \%$ at $4 x$. With statistical analysis showed that there were relation of frequency of teeth brush to oral hygiene school children $\left(X^{2}=98.5, d f=6\right.$ and $p=12.59$. This study concluded that oral health knowledge and exercise become successful in children from state elementary school at Palaran.
\end{abstract}

Key words: teeth brush, elementary school, oral hygiene

Korespondensi (correspondence): Silvia Anitasari, Bagian Mikrobiologi, Fakultas Kedokteran Universitas Mulawarman. Jln. Kerayan Kampus Gn. Kelua Samarinda Kalimantan Timur Indonesia.

\section{PENDAHULUAN}

Kesehatan gigi dan mulut masyarakat Indonesia masih merupakan hal yang perlu mendapat perhatian serius dari tenaga kesehatan, baik dokter maupun perawat gigi, hal ini terlihat bahwa penyakit gigi dan mulut masih diderita oleh $90 \%$ penduduk Indonesia. ${ }^{1}$ Penyakit gigi dan mulut yang banyak diderita masyarakat di Indonesia adalah penyakit jaringan penyangga gigi dan karies gigi, sumber dari kedua penyakit tersebut akibat terabaikannya kebersihan gigi dan mulut, sehingga terjadilah akumulasi plak. Plak adalah lapisan tipis yang melekat erat di permukaan gigi serta mengandung kumpulan bakteri. ${ }^{1-4}$

Berdasarkan teori Blum, status kesehatan gigi dan mulut seseorang atau masyarakat dipengaruhi oleh empat faktor penting yaitu keturunan, lingkungan (fisik maupun sosial budaya), perilaku, dan pelayanan kesehatan. Dari keempat faktor tersebut, perilaku memegang peranan yang penting dalam mempengaruhi status kesehatan gigi dan mulut. Di samping mempengaruhi status kesehatan gigi dan mulut secara langsung, perilaku dapat juga mempengaruhi faktor lingkungan dan pelayanan kesehatan. ${ }^{2,3,5}$

Sehubungan dengan pendapat di atas, maka frekuensi membersihkan gigi dan mulut sebagai bentuk perilaku akan mempengaruhi baik atau buruknya kebersihan gigi dan mulut, di mana akan mempengaruhi juga angka karies dan penyakit penyangga gigi. Namun jarang sekali dilakukan penelitian mengenai hubungan perilaku dengan tingkat kebersihan gigi dan mulut.

Di Samarinda penyakit gigi dan mulut termasuk dalam 10 besar penyakit yang banyak diderita penduduk Samarinda dan sampai sekarang belum adanya penelitian yang dilakukan untuk mengetahui faktor yang mempengaruhi terhadap kesehatan gigi dan mulut. ${ }^{6}$

Kecamatan Palaran terletak di daerah pinggiran Samarinda dengan jarak $\pm 45 \mathrm{~km}$ dari kota Samarinda atau 1 jam menyeberangi Sungai Mahakam. Penduduk daerah Palaran sebagian besar adalah petani dan buruh pabrik kayu dengan penghasilan cukup untuk memenuhi kebutuhan sehari-hari. 6

Di Kecamatan Palaran terdapat 1 puskesmas induk dan 5 puskesmas pembantu. Salah satu program puskesmas yaitu penyuluhan dan program sikat gigi masal yang selalu diadakan tiap tahun, tetapi tidak mengetahui sejauh mana keberhasilan dari program yang dilaksanakan tersebut. Untuk itu dilakukan suatu penelitian untuk mengetahui ada atau tidaknya hubungan frekuensi menyikat gigi dengan tingkat kebersihan gigi dan mulut siswa Sekolah Dasar Negeri di Kecamatan Palaran Kotamadya Samarinda Kalimantan Timur. 
Adapun tujuan penelitian ini adalah untuk mengetahui ada tidaknya hubungan frekuensi menyikat gigi dengan tingkat kebersihan gigi dan mulut pada siswa Sekolah Dasar Negeri di Kecamatan Palaran Kotamadya Samarinda Kalimantan Timur. 6

Diharapkan hasil penelitian ini dapat dijadikan sumber informasi ilmiah bagi Dinas Kesehatan Kota setempat dalam menyusun program kesehatan gigi dan dunia ilmu pengetahuan kedokteran gigi pada umumnya serta menjadi salah satu aspek bagi pengembangan penelitian lebih lanjut.

\section{BAHAN DAN METODE}

Jenis penelitian ini adalah observasional yang dilakukan di Sekolah Dasar Negeri di Kecamatan Palaran Kotamadya Samarinda. ${ }^{7}$ Populasi penelitian adalah siswa kelas 1-6 SDN di Kecamatan Palaran Kotamadya Samarinda. SDN yang diambil adalah SDN yang berada di Kecamatan Palaran dan mewakili tiap gugus yang ada, berdasarkan kriteria tersebut terpilih 10 SDN dan dari tiap SDN tersebut semua populasinya dipilih sebagai sampel penelitian. ${ }^{8}$

Variabel frekuensi menyikat gigi diukur dengan menggunakan kuesioner sedangkan variabel tingkat kebersihan mulut diukur dengan menggunakan indeks Oral Hygiene Index Simplified (OHI-S). ${ }^{1}$

\begin{tabular}{lcc}
\hline \multirow{2}{*}{ Indeks } & \multicolumn{2}{c}{ Kriteria indeks $O H I-S$} \\
\cline { 2 - 3 } & Angka & Kriteria \\
\hline OHI-S & $0-1,2$ & Baik \\
& $1,3-3$ & Sedang \\
& $3,1-6$ & Buruk \\
\hline
\end{tabular}

Hasil penelitian yang diperoleh dianalisis secara statistik dengan analisis Chi-square untuk mengetahui ada atau tidaknya hubungan frekuensi menyikat gigi dengan tingkat kebersihan gigi dan mulut siswa Sekolah Dasar Negeri di Kecamatan Palaran. Hipotesa uji yang dipakai adalah: Ho = tidak ada hubungan frekuensi menyikat gigi dengan tingkat kebersihan gigi dan mulut siswa Sekolah Dasar Negeri di Kecamatan Palaran, $\mathrm{H}_{1}=$ ada hubungan frekuensi menyikat gigi dengan tingkat kebersihan gigi dan mulut siswa Sekolah Dasar Negeri di Kecamatan Palaran.

\section{HASIL}

Hasil penilaian tingkat kebersihan mulut dengan menggunakan indeks $O H I-S$ pada 1650 siswa Sekolah Dasar Negeri kelas 1-6 Kecamatan Palaran Samarinda di dapatkan $6,73 \%$ siswa keadaan kebersihan gigi dan mulut baik; 59,03\% sedang; 34,24\% buruk (tabel 1). Oral Hygiene Index Simplified $(\mathrm{OHI}-\mathrm{S})$ rata-rata adalah 3 termasuk kebersihan gigi dan mulut sedang.
Tabel 1. Tingkat kebersihan gigi dan mulut siswa kelas 1-6 SDN Kecamatan Palaran Samarinda tahun 2004

\begin{tabular}{lcc}
\hline & $\mathrm{n}$ & $\begin{array}{c}\text { Persentase tingkat kebersihan } \\
\text { gigi dan mulut }\end{array}$ \\
\hline Baik & 111 & $6,73 \%$ \\
Sedang & 974 & $59,03 \%$ \\
Buruk & 565 & $34,24 \%$ \\
\hline
\end{tabular}

Hasil pengukuran frekuensi menyikat gigi siswa Sekolah Dasar Negeri Kecamatan Palaran, frekuensi menyikat gigi 1 kali sebanyak 2,18\%; 2 kali sebanyak 34,24\%; 3 kali sebanyak 61,88\%; sedangkan 4 kali sebanyak $1,70 \%$ (tabel 2).

Tabel 2. Frekuensi menyikat gigi siswa kelas 1-6 SDN Kecamatan Palaran Samarinda tahun 2004

\begin{tabular}{lcccc}
\hline & 1 kali & 2 kali & 3 kali & 4 kali \\
\hline Persentase frekuensi & $\mathrm{n}=36$ & $\mathrm{n}=565$ & $\mathrm{n}=1021$ & $\mathrm{n}=28$ \\
menyikat gigi & $2,18 \%$ & $34,24 \%$ & $61,88 \%$ & $1,70 \%$ \\
\hline
\end{tabular}

Bila frekuensi menyikat gigi dihubungan dengan tingkat kebersihan mulut terlihat pada frekuensi menyikat gigi 1 kali, persentase kebersihan gigi dan mulutnya baik $8,33 \%$, sedang $36,11 \%$, buruk $6,37 \%$. Pada frekuensi menyikat gigi 2 kali, persentase kebersihan gigi dan mulutnya baik $6,37 \%$, sedang $46,73 \%$, buruk $46,90 \%$. Pada frekuensi menyikat gigi 3 kali, persentase kebersihan gigi dan mulut baik 1,57\%, sedang 67,38\%, buruk $26,24 \%$. Pada frekuensi menyikat gigi 4 kali, persentase kebersihan gigi dan mulutnya baik $25 \%$, sedang $32,14 \%$, buruk $42,86 \%$ (tabel 3).

Tabel 3. Hubungan frekuensi menyikat gigi dengan tingkat kebersihan gigi dan mulut siswa kelas 1-6 SDN Kecamatan Palaran Samarinda tahun 2004

\begin{tabular}{lccccc}
\hline & & \multicolumn{4}{c}{ Tingkat kebersihan mulut } \\
\cline { 3 - 6 } & & Baik & Sedang & Buruk & Total \\
\hline $\begin{array}{l}\text { Frekuensi } \\
\text { menyikat }\end{array}$ gigi & 1 kali & 3 & 13 & 20 & 36 \\
& 2 kali & $(8,33 \%)$ & $(36,11 \%)$ & $(6,37 \%)$ & \\
& & $(6,37 \%)$ & $(46,73 \%)$ & $(46,90 \%)$ & \\
& 3 kali & 65 & 688 & 268 & 1021 \\
& & $(1,57 \%)$ & $(67,38 \%)$ & $(26,24 \%)$ & \\
& 4 kali & 7 & 9 & 12 & 28 \\
& & $(25 \%)$ & $(32,14 \%)$ & $(42,86 \%)$ & \\
& Total & 111 & 974 & 565 & 1650 \\
& & $(6,73 \%)$ & $(59,03 \%)$ & $(34,24 \%)$ & \\
\hline
\end{tabular}

Berdasarkan perhitungan statistik diperoleh $\mathrm{X}^{2}{ }_{\text {hitung }}=$ 98,42 sedangkan dari tabel Chi-square dengan $\mathrm{db}=(3-1)$ $(4-1)=6$ dan taraf kepercayaan $95 \%$, nilai $X_{\text {tabel }}^{2}=12,59$, sehingga $X^{2}$ hitung $=X^{2}$ tabel maka Ho ditolak, artinya ada 
hubungan frekuensi menyikat gigi dengan tingkat kebersihan gigi dan mulut.

\section{PEMBAHASAN}

Usaha pemerintah untuk meningkatkan kesehatan gigi dan mulut masyarakat Indonesia sangat membutuhkan peranserta masyarakat sendiri terutama perubahan perilaku, melalui program penyuluhan dan pelatihan. Program penyuluhan kesehatan gigi dan mulut dan pelatihan sikat gigi masal merupakan suatu program yang dilakukan oleh pemerintah melalui puskesmas setiap tahun. ${ }^{6}$

Dari hasil penelitian kesehatan gigi dan mulut siswa kelas 1-6 SDN Kecamatan Palaran yang sudah pernah mendapatkan penyuluhan dan pelatihan cara menyikat gigi yang baik dan benar, didapatkan tingkat kebersihan mulut (OHI-S) mereka rata-rata 3 dengan kriteria sedang (tabel 1), sedangkan dalam hal menyikat gigi sebagian besar siswa ini mengerti bahwa frekuensi menyikat gigi yang baik adalah 2-3 kali sehari (tabel 2). Hal ini menunjukkan program penyuluhan kesehatan gigi dan mulut serta sikat gigi masal mengenai target tujuan. Jika kita hubungkan frekuensi menyikat gigi dengan tingkat kebersihan gigi dan mulut siswa SDN Palaran, berdasarkan hasil statistik ada pengaruh frekuensi menyikat gigi dengan tingkat kebersihan mulut siswa tersebut. Hal ini terlihat secara jelas pada (tabel 3), di mana siswa yang menyikat gigi dengan frekuensi 4 kali dengan tingkat kebersihan gigi dan mulut baik persentasenya lebih tinggi dibandingkan dengan frekuensi menyikat gigi 1 kali, 2 kali dan 3 kali.

Berdasarkan penelitian Hawkins, ${ }^{2}$ pendidikan kesehatan yang diberikan beserta dengan pelatihan akan memberikan hasil yang optimal. Hal ini terbukti pada penelitian terhadap siswa SDN di Kecamatan Palaran, di mana penyuluhan dan sikat gigi masal yang dilaksanakan setiap tahun, mempengaruhi perilaku mereka dalam menyikat gigi (tabel 3). Walaupun terdapat hubungan frekuensi menyikat gigi dengan tingkat kebersihan gigi dan mulut siswa SDN di kecamatan Palaran tetapi tingkat kebersihan gigi dan mulutnya rata-rata sedang bukan baik (tabel 1).

Dari hasil penelitian ini, dapat disimpulkan terdapat hubungan frekuensi menyikat gigi dengan tingkat kebersihan gigi dan mulut siswa SDN Palaran Samarinda Provinsi Kalimantan Timur.

\section{UCAPAN TERIMA KASIH}

Penelitian ini dapat terlaksana karena dukungan berbagai pihak. Untuk itu, pada kesempatan ini peneliti mengucapkan terima kasih kepada dr. H. Hatmoko, Kepala Puskesmas dan drg. Liliwati, penanggung jawab poli gigi Puskesmas Palaran beserta seluruh staf atas kerja sama yang telah diberikan.

\section{DAFTAR PUSTAKA}

1. Departemen Kesehatan RI. Profil kesehatan gigi dan mulut di Indonesia pada Pelita V. Jakarta: Departemen Kesehatan RI; 1994.

2. Hawkins RJ, et al. Oral hygiene knowledge of high-risk grade one children: an evaluation of two methods of dental health education. J community Dentistry and Epidemiology 2000; 28: 336-43.

3. Spolsky VW. Epidemiology of gingival and periodontal disease In: Carranza FA, Newman MG, editors. Clinical periodontology. $9^{\text {th }}$ ed. Philadelphia: WB Saunders Co; 2000. p. 84.

4. Veld HI. Ilmu kedokteran gigi pencegahan. Sutatmi Suryo. Yogyakarta: Universitas Gadjah Mada; 1993. h. 59.

5. Notoatmodjo S. Pendidikan dan perilaku kesehatan. Edisi 1. Jakarta: Rineka Cipta; 2003. h. 120-34.

6. Dinas Kesehatan Kota Samarinda. Profil kesehatan kotamadya Samarinda. Samarinda: Dinas Kesehatan Kota; 2004.

7. Bhisma M. Prinsip dan metode Riset Epidemiologi. Edisi 1. Yogyakarta: Universitas Gadjah Mada; 1967.

8. Lameshow S. Adequacy of sample size in health studies. Chichester: WHO-John Wiley \& Sons; 1990. p. 42. 